\title{
Expression of Enamel Proteins in Rough Endoplasmic Reticulum and Golgi Complex in Human Dental Germs
}

\author{
Expresión de Proteínas del Esmalte en Retículo Endoplásmico Rugoso \\ y Complexo golgiensis en Gérmenes Dentales Humanos
}

\begin{abstract}
Francisco Javier Gutiérrez-Cantú ${ }^{1}$; Alma Lilián Guerrero-Barrera²; Wulfrano Sánchez Meraz ${ }^{1}$; Amaury de Jesús Pozos-Guillen'; Héctor Flores-Reyes'; Eduardo Alejandro Gutiérrez Robles ${ }^{3}$; Humberto Mariel Murga ${ }^{1}$; Gabriel Fernando Romo Ramírez ${ }^{1} \&$ Jairo Mariel Cárdenas ${ }^{1}$
\end{abstract}

GUTIÉRREZ-CANTÚ, F. J.; GUERRERO-BARRERA, A. L.; SÁNCHEZ, M. W.; POZOS-GUILLEN, A. J.; FLORES-REYES, H.; GUTIÉRREZ ROBLES E. A.; MARIEL, M. H.; ROMO RAMÍREZ, G. F. \& MARIEL C. J. Expression of enamel proteins in rough endoplasmic reticulum and Golgi complex in human dental germs. Int. J. Morphol., 35(2): 435-441, 2017.

SUMMARY: Tooth enamel is the hardest tissue in the body. The organic matrix configuration is provided by the main proteins amelogenin, ameloblastin and enamelysin (MMP20), an enzyme that helps to shape the matrix. The aim of this study was to determine by histochemistry the expression of amelogenin and enamelysin through the rough endoplasmic reticulum in the late stages of amelogenesis, and its expression in the Complexus golgiensis (Golgi complex / Golgi apparatus) in the early stages in human fetuses. In early stages a colocalization of both proteins inside the Golgi apparatus was found, being more evident the relationship between Golgi and amelogenin $(99.92 \%)$. In the late stage, a colocalization of both proteins and rugged endoplasmic reticulum was found. With enamelysin being more evident in relation with rough endoplasmic reticulum (99.95\%). Our findings demonstrated the presence of amelogenin and enamelysin in odontoblast and ameloblast. However, the presence of these two proteins in odontoblast remains unknown.

KEY WORDS: Rough endoplasmic reticulum; Complexus golgiensis; Golgi apparatus; Enamelysin; Amelogenin.

\section{INTRODUCTION}

Dental enamel is the hardest substance in the body. Its hardness is intermediate between that of iron and carbon steel, yet it also has a relatively high elasticity (Cole \& Eastoe, 1988). Amelogenesis consists of several stages, including the secretory, transition, and maturation stages of enamel development (Bartlett et al., 1999; Bartlett et al., 2006). Amelogenin is the most abundant and bestcharacterized enamel matrix protein. The enamel layer of developing teeth contains a complex mixture of amelogenin peptides (Oida et al., 2002).

During tooth morphogenesis, epithelial cells differentiate into secretory ameloblasts, which synthesize and secrete enamel matrix proteins (Termine et al., 1980; Simmer et al., 1994; Ogata et al., 1998). The enamel matrix is secreted by epithelial-derived ameloblasts, as a protein of the matrix that self-assembles to promote mineral growth
(Sasaki \& Shimokawa, 1979; Fincham et al., 1995; Finchman \& Simmer, 1997; Paine et al., 2005). Amelogenin, which is the dominant protein in the developing enamel matrix, plays an essential role in the control and modulation of enamel crystal growth (Tanimoto et al., 2008a). Immature enamel matrix consists of about $30 \%$ proteins by weight, almost all of which is removed from the tissue with increasing mineralization (Gibson et al., 1991; Ryu et al., 1998; Veis et al., 2000; Hoang et al., 2002; Nakayama et al., 2010). Enamel formation is a dynamic process that involves crystal maturation, which is concomitant with matrix proteolysis (Smith et al., 1989; Sun et al., 2008).

Two proteases of the matrix, metalloproteinase 20 (MMP-20, or enamelysin) and kallikrein 4 (KLK4, or enamel matrix serine proteinase 1, EMSP1), are known to play important roles in removing enamel proteins during

\footnotetext{
${ }^{1}$ Department of Morphology, Master of orthodontics, Faculty of Dentistry, University of San Luis Potosí, San Luis Potosí, México.

${ }^{2}$ Basic Sciences Center, University of Aguascalientes, Aguascalientes, México.

${ }^{3}$ Faculty of Science, University of San Luis Potosí, San Luis Potosí, México.
} 
GUTIÉRREZ-CANTÚ, F. J.; GUERRERO-BARRERA, A. L.; SÁNCHEZ, M. W.; POZOS-GUILLEN, A. J.; FLORES-REYES, H.; GUTIÉRREZ ROBLES E. A.; MARIEL, M. H.; ROMO RAMíREZ, G. F. \& MARIEL C. J. Expression of enamel proteins in rough endoplasmic reticulum and Golgi complex in human dental germs. Int. J. Morphol., 35(2): 435-441, 2017.

amelogenesis. High concentrations of fluoride down-regulate the expression of MMP-20 (Zhang et al., 2006) and inhibit MMP-20 activity (DenBesten et al., 2002). The resorption of enamel proteins by mature ameloblasts may be another mechanism whereby matrix proteins are removed from developing enamel (Smith, 1998; Duan et al., 2011). MMP20 is expressed in ameloblasts and odontoblasts in the developing teeth and helps in degrading amelogenin (Varun et al., 2012).

Secretory-stage ameloblasts are responsible for many important processes necessary for enamel formation, including: alternative mRNA splicing, translation and secretion of enamel proteins (amelogenin, ameloblastin, enamelin, MMP-20), selective reabsorption and degradation of cleavage products, establishment and regulation of the influx of calcium and phosphate ions, and maintenance of extracellular $\mathrm{pH}$ and ionic strength (Simmer \& Fincham, 1995; Fincham et al., 1999). Enamel is also uniquely composed of extremely long and narrow crystals, packed into parallel arrays, called enamel rods, which can form intricate interwoven patterns.

Its high degree of structural organization strongly suggests that extracellular enamel matrix proteins secreted by ameloblasts during early stages of amelogenesis must regulate this organization, as collagen does in bone and dentin (Margolis et al., 2006). The known expression of extracellular matrix proteins during early and late stages of amelogenesis could give more understanding about the secretion, formation and maturation of the hard tissues of dental organ, which plays a primordial role in the malformations development during the embrionary stages.

The aim of this study was to evaluate the expression of amelogenin and enamelysin through the rough endoplasmic reticulum in the late stages of amelogenesis as well as its expression in the Complexus golgiensis (Golgi complex / Golgi apparatus) in early stages.

\section{MATERIAL AND METHOD}

Almost all reagents were from Sigma Aldrich. Protocol was approved by the human ethic committee of Zacatecas General Hospital, Mexico. Human fetal jaws from six amphitheater fetuses between 14 and 22 weeks of intrauterine life, without any defect, donated by Pathology Department were used.

Jaws were dissected and separated into upper and lower, and segmented into left and right sections, obtaining
24 samples. They were decalcified in $10 \%$ EDTA for 30 days, and placed 30 min into 1x PBS. They were processed by histological technique obtaining $5 \mathrm{~mm}$ sections. Specimen sections from both, rough endoplasmic reticulum and Golgi apparatus in early and late stages of amelogenesis were selected.

For early bell stage, anti-amelogenin antibodies prepared using amelogenin $(250 \mathrm{mg}$ ) from 11-day-old rats were selected (Gutiérrez-Cantú et al., 2011). Deparaffinized sections were autoclaved in $0.01 \mathrm{M}$ sodium citrate for antigenic retrieval (Hayat et al., 2002), and labeled by indirect immunohistochemistry with anti-amelogenin polyclonal antibody, 1:1,000, using as a secondary antibody Qdot 565 goat anti-rabbit 1:500 (Molecular Probes, Eugene, Oregon, USA). Second labeling was done with antienamelysin polyclonal antibody 1:50; (Chemicon International, Temecula, CA, USA) and as secondary antibody Qdot 525 goat anti-rabbit 1:500 was used. Third labeling was done with monoclonal antibody: anti-Golgi 1:200 (anti-golgin-97, human, Molecular Probes, USA).

For late stage were selected the same protein markers and Alexa Fluor 488 to the rough endoplasmic reticulum immunofluorescence using the monoclonal antibody of the kit First SelectFX Alexa Fluor 488 Endoplasmic Reticulum 1:200 (anti-protein disulfide isomerase, Molecular Probes, USA). Sections were counter-stained with Harris hematoxylin, dehydrated, cleared, and assembled with Entellan resin (Fermont, Mexico City, Mexico). Images were obtained with a laser confocal microscope (DMI4000B: Leica Microsystems, Wetzlar: Germany) and analyzed with the software LAF.

\section{RESULTS}

Golgi apparatus-Enamelysin- Amelogenin Colocalization. After labeling, through the images from confocal-microscope, it is observed in the figure 1: A) a label is observed using as a first antibody Anti-Golgi (molecular probes) second antibody: Alexa Fluor 488 Secondary Antibody (Molecular Probes) (green) the enamel organ can be found on the top right side, on the left side of the dental papilla. It has been identified a mayor activity on the stellate reticulum cells. B) it was mark using a first antibody Antyamelogenin (produced on the laboratory) second antibody Qdot Secondary Antibody 565 conjugate (molecular probes). (light blue) amelogenin granules were observed in stellate reticulum cells and in dental papilla. C) it was marked using the first antibody Anti-Enamelisina (CHEMICON), second antibody Qdot Secondary Antibody 525 conjugate 
GUTIÉRREZ-CANTÚ, F. J.; GUERRERO-BARRERA, A. L.; SÁNCHEZ, M. W.; POZOS-GUILLEN, A. J.; FLORES-REYES, H.; GUTIÉRREZ ROBLES E. A.; MARIEL, M. H.; ROMO RAMÍREZ, G. F. \& MARIEL C. J. Expression of enamel proteins in rough endoplasmic reticulum and Golgi complex in human dental germs. Int. J. Morphol., 35(2): 435-441, 2017.
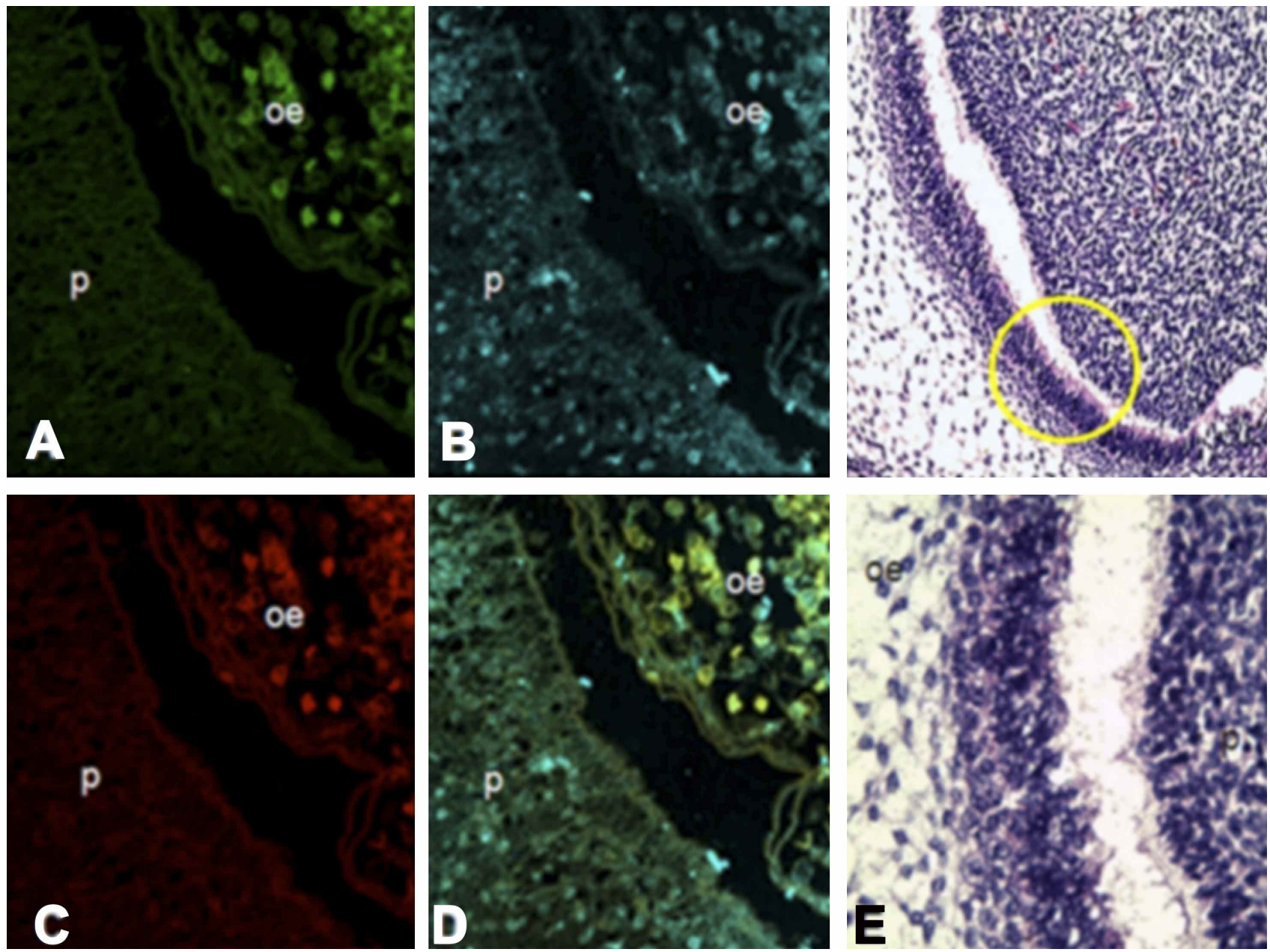

Figure 1. Triple immunofluorescent labeling of human tooth germ Golgi apparatus-Enamelysin- Amelogenin. Confocal microscope, double staining 600x: A) Anti-Golgi (Molecular Probes), 2nd antibody: Alexa Fluor 488 Secondary Antibody (Molecular Probes). B) Anti-Amelogenin (UAA), $2^{\circ}$ antibody: Qdot Secondary Antibody 565 conjugate (Molecular Probes). C) Anti-enamelysin (chemicon), 2nd antibody: Qdot Secondary Antibody 525 conjugate (Molecular Probes D) Colocalization. E) Human tooth germ, early bell stage. HE. Optical Microscopy, 100x. $\mathrm{P}=$ papilla; oe = enamel organ.

(Molecular Probes) (red) enamelysin granules were identified on the stellate reticulum cells and the dental papilla, it is was more notable on the stellate reticulum, creating a reservoir into the basement membrane. D) colocalization of the Golgi apparatus and enamelysin, it was observed the relationship between both markings and the accumulation of the amelogenin and enamelisin in the dental papilla and on the enamel organ.

Table I shows the percentage of observed colocalization in early stage. it identifies on the EnamelysinGolgi Apparatus mayor pearson's correlation (0.9618), Overlap coefficient (0.9788), Colocalization rate (99.92\%) and Colocalization area $\left(9524.23 \mathrm{~mm}^{2}\right)$ with respect to the observed on the amelogenin-Golgi Apparatus. the colocalization rate for both were $90.81 \%$.
Rough Endoplasmic Reticulum - EnamelysinAmelogenin Colocalization. On the Figure 2 was identified: A) a mark with Anti-RE (molecular probes); second antibody Alexa Fluor 488 secundary antibody (molecular probes) the arrangement of the rough endoplasmic reticulum was identified in the enamel organ as much as in the dental papi1la. (green) B) labeling with antiamelogenin (produced on the laboratory) second antibody: Qdot Secondary Antibody 565 conjugate (Molecular Probes, USA), in which it was observed a labelling of amelogenin on the enamel organ and the dental papilla and delimitating the mantle dentin, being more remarkable on the amelobasts and the odontoblasts. (light blue). C) Anti-enamelisin (Chemicon International, USA), second antibody: Qdot Secondary Antibody 525 conjugate (Molecular Probes, USA), it can be observed the disposition of the enamelisin around the mantle dentin that 
GUTIÉRREZ-CANTÚ, F. J.; GUERRERO-BARRERA, A. L.; SÁNCHEZ, M. W.; POZOS-GUILLEN, A. J.; FLORES-REYES, H.; GUTIÉRREZ ROBLES E. A.; MARIEL, M. H.; ROMO RAMíREZ, G. F. \& MARIEL C. J. Expression of enamel proteins in rough endoplasmic reticulum and Golgi complex in human dental germs. Int. J. Morphol., 35(2): 435-441, 2017.

Table I. Colocalization of Amelogenin, Enamelysin and Golgi apparatus (Complexus golgiensis).

\begin{tabular}{lccc}
\hline Colocalization & $\begin{array}{c}\text { Amelogenin- } \\
\text { Golgi Apparatus }\end{array}$ & $\begin{array}{c}\text { Enamelysin- } \\
\text { Golgi Apparatus }\end{array}$ & $\begin{array}{c}\text { Amelogenin- } \\
\text { Enamelysin }\end{array}$ \\
\hline Pearson's correlation & 0.5248 & 0.9618 & 0.5532 \\
Overlap coefficient & 0.7499 & 0.9788 & 0.7672 \\
Colocalization rate & $78.82 \%$ & $99.92 \%$ & $90.81 \%$ \\
Colocalization area & $8231.22 \mu \mathrm{m}^{2}$ & $9524.23 \mu \mathrm{m}^{2}$ & $11655.55 \mu \mathrm{m}^{2}$ \\
Area image & $30486.28 \mu \mathrm{m}^{2}$ & $30486.28 \mu \mathrm{m}^{2}$ & $30486.28 \mu \mathrm{m}^{2}$ \\
Area foreground & $10443.55 \mu \mathrm{m}^{2}$ & $9532.31 \mu \mathrm{m}^{2}$ & $12835.00 \mathrm{~m}^{2}$ \\
Area background & $20042.73 \mu \mathrm{m}^{2}$ & $20953.97 \mu^{2}$ & $17651.28 \mu \mathrm{m}^{2}$ \\
\hline
\end{tabular}
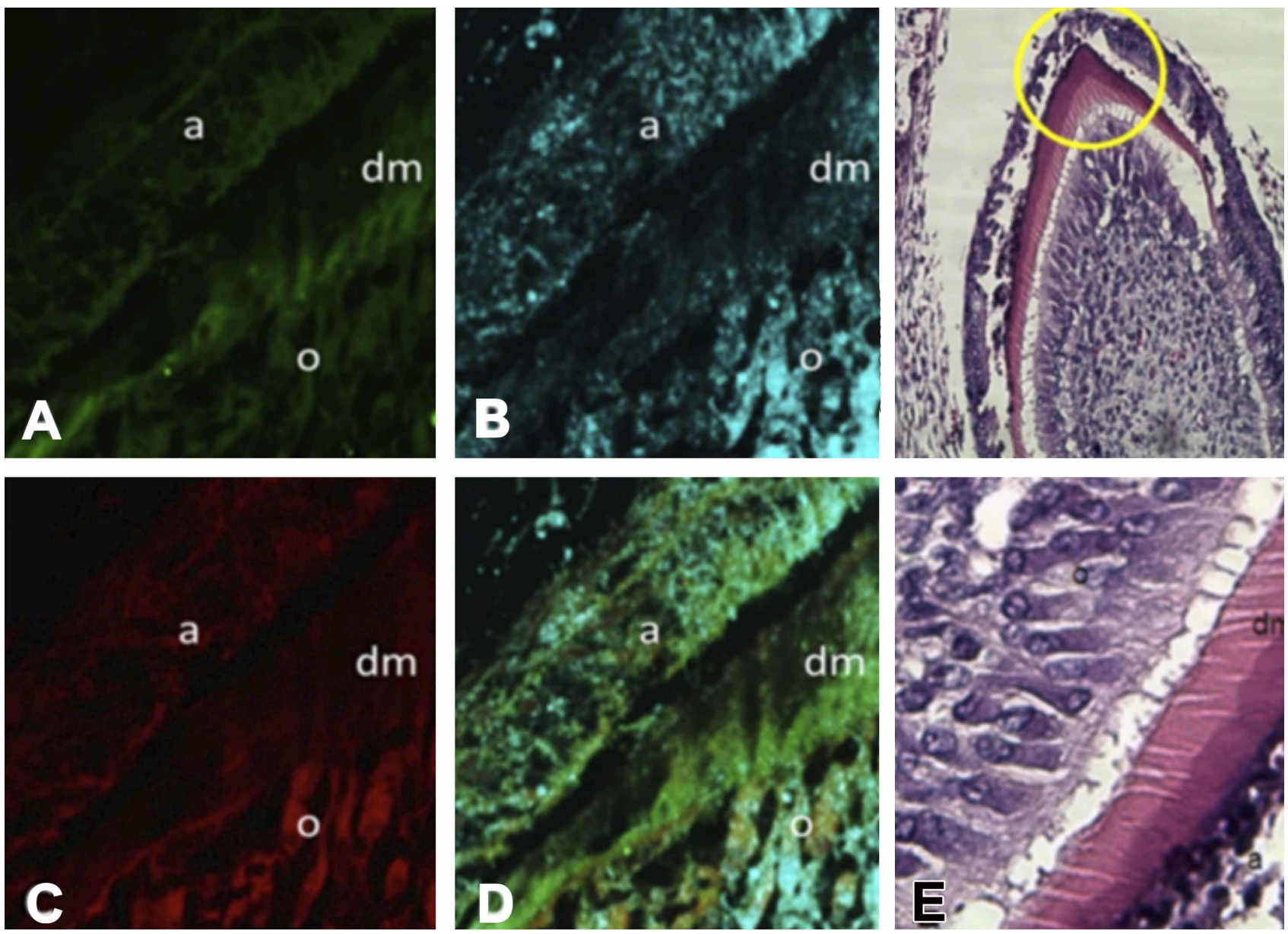

Fig.2. Triple immunofluorescent labeling of human tooth germ Amelogenin-Enamelysin-ER. Confocal Microscopy, x 600: A) Antiamelogenin (Hokudo), $2^{\text {nd }}$ antibody: Qdot Secondary Antibody 565 conjugate (Molecular Probes). B) Anti-enamelysin (Chemicon), $2^{\text {nd }}$ antibody: Qdot Secondary Antibody 525 conjugate (Molecular Probes). C) Anti-ER (Molecular Probes), $2^{\text {nd }}$ antibody: Alexa Fluor 488 Secondary Antibody (Molecular Probes). D) Colocalization of the three markers. E) Human tooth germ, Late Bell stage. H-E. Optical Microscopy, 400x. Ameloblasts (a), mantle dentin (dm), odontoblasts (o).

is mineralized just as the ameloblast and stronger than the odontoblast (red). D): Colocalization of the Golgi apparatus and amelogenin, the relationship between the labels and the accumulation of amelogenin and enamelisin on the odontoblast (right lower portion).

In Table II the percentages of colocalization in late stage were presented. it identifies on Enamelysin-Rough Endoplasmic Reticulum mayor pearson's correlation (0.8729), Overlap coefficient (0.9492), Colocalization rate $(99.95 \%)$ and Colocalization area $\left(7289.86 \mathrm{~mm}^{2}\right)$ with respect to the observed on the Amelogenin- Rough Endoplasmic Reticulum. The colocalization rate for both were $78.65 \%$. 
GUTIÉRREZ-CANTÚ, F. J.; GUERRERO-BARRERA, A. L.; SÁNCHEZ, M. W.; POZOS-GUILLEN, A. J.; FLORES-REYES, H.; GUTIÉRREZ ROBLES E. A.; MARIEL, M. H.; ROMO RAMÍREZ, G. F. \& MARIEL C. J. Expression of enamel proteins in rough endoplasmic reticulum and Golgi complex in human dental germs. Int. J. Morphol., 35(2): 435-441, 2017.

Table II. Colocalization of Amelogenin, Enamelysin and Rough Endoplasmic Reticulum.

\begin{tabular}{lccc}
\hline Colocalization & $\begin{array}{c}\text { Amelogenin- Rough } \\
\text { Endoplasmic } \\
\text { Reticulum }\end{array}$ & $\begin{array}{c}\text { Enamelysin- } \\
\text { Rough Endoplasmic } \\
\text { Reticulum }\end{array}$ & $\begin{array}{c}\text { Amelogenin- } \\
\text { Enamelysin }\end{array}$ \\
\hline Pearson's correlation & 0.3729 & 0.8729 & 0.5197 \\
Overlap coefficient & 0.6917 & 0.9492 & 0.7680 \\
Colocalization rate & $53.29 \%$ & $99.95 \%$ & $78.65 \%$ \\
Colocalization area & $3739.39 \mu \mathrm{m}^{2}$ & $7289.86 \mu \mathrm{m}^{2}$ & $7843.84 \mu \mathrm{m}^{2}$ \\
Area image & $14908.43 \mu \mathrm{m}^{2}$ & $14908.43 \mu \mathrm{m}^{2}$ & $14908.43 \mathrm{~m}^{2}$ \\
Area foreground & $7016.54 \mu \mathrm{m}^{2}$ & $7293.50 \mu \mathrm{m}^{2}$ & $9973.50 \mathrm{~m}^{2}$ \\
Area background & $7891.90 \mu \mathrm{m}^{2}$ & $7614.94 \mu \mathrm{m}^{2}$ & $4934.94 \mu \mathrm{m}^{2}$ \\
\hline
\end{tabular}

\section{DISCUSSION}

Amelogenin and enamelysin are structural proteins in the enamel matrix of developing teeth. The temporal and spatial patterns of enamelysin expression in developing of the tooth have not been characterized, while controversy remains with respect to amelogenin expression by ameloblasts and odontoblast.

Odontogenesis process is not well understood in humans (El Rouby et al., 2010; Kavitha et al., 2010; Nandasena et al., 2010; Sumita et al., 2010). Enamelysin and amelogenin immunolocalization has been performed in mice's, rats, and pigs incisors (Caterina et al., 2000; Bourd-Boittin et al., 2004) In humans, the biochemical role of amelogenin and enamelysin in enamel mineralization has been described (Sun et al.); Tanimoto et al., 2008b; Deshpande et al., 2010).

The amelogenins, its family of extracellular matrix proteins of the dental enamel, are transiently but abundantly expressed by ameloblasts during tooth development. Amelogenins seem to regulate the formation of crystallites during the secretory stage of enamel development, while they are specifically degraded during the tooth maturation. However, there is no evidence of the route that follows the secretion of these proteins during the formation and post transductional process.

This study evaluated the expression of amelogenin and enamelysin through the rough endoplasmic reticulum in the late stages of amelogenesis as well as its expression in the Golgi apparatus in early stages whose expression pattern is restricted to the growth of teeth and stood in ameloblasts and odontoblasts (Caterina et al.; Bègue-Kirn et al., 1998).

Bourd-Boittin used an electron immunogold-staining and found that MMP-20 at the early stages showed the high labeling intensity in the stratum intermedium. In the presecretory ameloblast and odontoblast, staining was mainly cytosolic and nuclear, although a few vesicles were also stained (Bourd-Boittin et al.). No labeling was detected in the nonmineralized dentin, basement membrane, matrix vesicles, or collagen fibrils. In the present study it was found that MMP20 always was observed intracellular near of the cellular membrane.

Simmer J. observed that the enamelysin is expressed by both ameloblast and odontoblast (Simmer \& Hu, 2002). Bourd-Boittin et al. observed also staining of MMP-20 in the odontoblast, in some pulp cells and in the stellate reticulum. This is coincident with our study, were we found staining of enamelysin in presecretory odontoblast and papilla cells. This finding until now is not yet to be clearly determined. The significance of the apparition of amelogenin in papilla is not clear. We believe that this finding could be due to degradation of amelogenin by enamelysin, and these are just some rests of amelogenin.

Numerous early studies, using immunohistochemistry, identified amelogenins in endocytic vesicles and lysosomes within odontoblasts before mineralization of mantle dentin in the mouse (Nakamura \& Ozawa, 1997), along the cell surfaces and processes of odontoblast, and in young odontoblast of the hamster (Karg et al., 1997). Recently, amelogenin mRNA transcripts have been amplified from mouse dental mesenchyme and immortalized odontoblast-like cells (Papagerakis et al., 2008) and porcine odontoblast (Nagase et al., 2006). Studies of rodent teeth by in situ hybridization failed to find amelogenin transcripts in odontoblasts (Karg et al.; Torres-Quintana et al., 2005), suggesting that transcripts may be present at very low levels. The superposition of enamelysin and amelogenin in rough endoplasmic reticulum in the late stages it shows that enamelysin are inside of the organelle and that amelogenin is partially inside, and the other part have been partially expressed. 
GUTIÉRREZ-CANTÚ, F. J.; GUERRERO-BARRERA, A. L.; SÁNCHEZ, M. W.; POZOS-GUILLEN, A. J.; FLORES-REYES, H.; GUTIÉRREZ ROBLES E. A.; MARIEL, M. H.; ROMO RAMíREZ, G. F. \& MARIEL C. J. Expression of enamel proteins in rough endoplasmic reticulum and Golgi complex in human dental germs. Int. J. Morphol., 35(2): 435-441, 2017.

We found a high concentration of enamelysin in Golgi apparatus in early stages and amelogenin in a lower concentration. This could mean that amelogenin has been secreted already before enamelysin secretion, in order to form the organic matrix that will be mineralized later by enamelysin.

Our present data showed, amelogenin in a $53.29 \%$ in rough endoplasmic reticulum in enamel organ and dental papilla in later stages; which means the start of the amelogenin synthesis occurring. As well as enamelysin present in 99.95 $\%$ in odontoblast and ameloblast. Our findings demonstrated the presence of amelogenin and enamelysin in odontoblast and ameloblast. However, the presence of these two proteins in odontoblast remains unknown.
In this work we found a great quantity of amelogenin and enamelysin in odontoblast as well as dental papilla in late stages, which would suggest that odontoblast produce itself amelogenin and enamelysin. These findings could explain the role of these proteins during the mineralization and maturation of dentin as structural proteins during the first stage of mineralization.

\section{ACKNOWLEDGEMENTS}

To the clinic of Orthodontics and Dentomaxilofacial Orthopedics of the San Luis Potosi University for the equipment and installations to perform this research.

GUTIÉRREZ-CANTÚ, F. J.; GUERRERO-BARRERA, A. L.; SÁNCHEZ, M. W.; POZOS-GUILLEN, A. J.; FLORES-REYES, H.; GUTIÉRREZ ROBLES E. A.; MARIEL, M. H.; ROMO RAMÍREZ, G. F. \& MARIEL C. J. Expresión de proteínas del esmalte en retículo endoplásmico rugoso y Complexo golgiensis en gérmenes dentales humanos. Int. J. Morphol., 35(2) :435-441, 2017.

RESUMEN: El esmalte dental es el tejido más duro del cuerpo. La configuración de la matriz orgánica es proporcionada por las proteínas principales amelogenina, ameloblastina y enamelisina (MMP20), una enzima que ayuda a dar forma a la matriz. El objetivo de este estudio fue determinar mediante histoquímica la expresión de amelogenina y enamelisina a través del retículo endoplasmático rugoso en las últimas etapas de la amelogénesis , y su expresión en el Complexo golgiensis en las primeras etapas de formación en fetos humanos. En las primeras etapas se observó colocalización de ambas proteínas en el interior del Complexo golgiensis, siendo más evidente la relación entre Golgi y amelogenina (99,92\%). En la última etapa, se identificó una colocalización de ambas proteínas y retículo endoplásmico rugoso. Resulto más evidente la enamelisina en relación con el retículo endoplasmático rugoso (99,95 \%). Nuestros resultados demostraron la presencia de amelogenina y enamelisina en odontoblastos y ameloblastos, sin embargo se desconoce la presencia de estas dos proteínas en odontoblastos .

PALABRAS CLAVE: Retículo endoplásmico rugoso; Complexo golgiensis; Enamelisina; Amelogenina.

\section{REFERENCES}

Bartlett, J. D. \& Simmer, J. P. Proteinases in developing dental enamel. Crit. Rev. Oral Biol. Med., 10(4):425-41, 1999.

Bartlett, J. D.; Skobe, Z.; Lee, D. H.; Wright, J. T.; Li, Y.; Kulkarni, A. B. \& Gibson, C. W. A developmental comparison of matrix metalloproteinase20 and amelogenin null mouse enamel. Eur. J. Oral Sci., 114 Suppl. 1:18-23. 2006

Bégue-Kirn, C.; Krebsbach, P. H.; Bartlett, J. D. \& Butler, W. T. Dentin sialoprotein, dentin phosphoprotein, enamelysin and ameloblastin: toothspecific molecules that are distinctively expressed during murine dental differentiation. Eur. J. Oral Sci, 106(5):963-70, 1998.

Bourd-Boittin, K.; Septier, D.; Hall, R.; Goldberg, M. \& Menashi, S. Immunolocalization of enamelysin (matrix metalloproteinase-20) in the forming rat incisor. J. Histochem. Cytochem, 52(4):437-45, 2004.

Caterina, J.; Shi, J.; Sun, X.; Qian, Q.; Yamada, S.; Liu, Y.; Krakora, S.; Bartlett, J. D.; Yamada, Y.; Engler, J. A.; Birkedal-Hansen, H. \& Simmer, J. P. Cloning, characterization, and expression analysis of mouse enamelysin. J. Dent. Res., 79(9):1697-703, 2000.

Cole, A. S. \& Eastoe, J. E. Biochemistry and Oral Biology. 2nd ed. London, Wright, 1988

DenBesten, P. K.; Yan, Y.; Featherstone, J. D.; Hilton, J. F.; Smith, C. E. \& $\mathrm{Li}, \mathrm{W}$. Effects of fluoride on rat dental enamel matrix proteinases. Arch. Oral Biol., 47(11):763-70, 2002.
Deshpande, A. S.; Fang, P. A.; Simmer, J. P.; Margolis, H. C. \& Beniash, E. Amelogenin-collagen interactions regulate calcium phosphate mineralization in vitro. J. Biol. Chem., 285(25):19277-87, 2010.

Duan, X.; Mao, Y.; Wen, X.; Yang, T. \& Xue, Y. Excess fluoride interferes with chloride-channel-dependent endocytosis in ameloblasts. J. Dent. Res., 90(2):175-80, 2011.

El Rouby, E. H.; Bashir, M. H. \& Korany, N. S. The effect of lathyrism on dentin structure of the rat incisors: a morphometric and scanning electron microscopic investigation. J. Oral Pathol. Med., 39(5):424-30, 2010.

Fincham, A. G.; Moradian-Oldak, J. \& Simmer, J. P. The structural biology of the developing dental enamel matrix. J. Struct. Biol., 126(3):270-99, 1999.

Fincham, A. G.; Moradian-Oldak, J.; Diekwisch, T. G. H.; Lyaruu, D. M.; Wright, J. T.; Bringas Jr., P. \& Slavkin, H. C. Evidence for amelogenin "nanospheres" as functional components of secretory-stage enamel matrix. J. Struct. Biol., 115(1):50-9, 1995.

Fincham, A. G. \& Simmer, J. P. Amelogenin proteins of developing dental enamel. Ciba Found. Symp., 205:118-130, 1997.

Gibson, C.; Golub, E.; Herold, R.; Risser, M.; Ding, W.; Shimokawa, H.; Young, M.; Termine, J. \& Rosenbloom, J. Structure and expression of the bovine amelogenin gene. Biochemistry, 30(4):1075-9, 1991.

Gutiérrez-Cantú, F. J.; Feria-Velasco, A.; Palacios-Arenas, L. N.; Alvarado- 
GUTIÉRREZ-CANTÚ, F. J.; GUERRERO-BARRERA, A. L.; SÁNCHEZ, M. W.; POZOS-GUILLEN, A. J.; FLORES-REYES, H.; GUTIÉRREZ ROBLES E. A.; MARIEL, M. H.; ROMO RAMÍREZ, G. F. \& MARIEL C. J. Expression of enamel proteins in rough endoplasmic reticulum and Golgi complex in human dental germs. Int. J. Morphol., 35(2): 435-441, 2017.

Estrada, K. N.; Avelar-González, F. J.; Flores-Reyes, H.; Mariel-Cárdenas, J. \& Guerrero-Barrera, A. L. Amelogenin and enamelysin localization in human dental germs. In Vitro Cell Dev. Biol. Anim., 47(56):355-60, 2011.

Hayat, M. A. Microscopy, Immunohistochemistry, and Antigen Retrieval Methods: For Light and Electron Microscopy. New York, Kluwer Academic/Plenum Publishers, 2002. pp.71-92.

Hoang, A. M.; Klebe, R. J.; Steffensen, B.; Ryu, O. H.; Simmer, J. P. \& Cochran, D. L. Amelogenin is a cell adhesion protein. J. Dent. Res., 81(7):497-500, 2002.

Karg, H. A.; Burger, E. H.; Lyaruu, D. M.; Wöltgens, J. H. \& Bronckers, A. L. Gene expression and immunolocalisation of amelogenins in developing embryonic and neonatal hamster teeth. Cell Tissue Res., 288(3):545-55, 1997.

Kavitha, B.; Priyadharshini, V.; Sivapathasundharam, B. \& Saraswathi, T. R. Role of genes in oro-dental diseases. Indian J. Dent. Res., 21(2):2704, 2010.

Margolis, H. C.; Beniash, E. \& Fowler, C. E. Role of macromolecular assembly of enamel matrix proteins in enamel formation. J. Dent. Res., 85(9):775-93, 2006.

Nagase, H.; Visse, R. \& Murphy, G. Structure and function of matrix metalloproteinases and TIMPs. Cardiovasc. Res., 69(3):562-73, 2006.

Nakamura, H. \& Ozawa, H. Immunolocalization of CD44 and the ezrinradixin-moesin (ERM) family in the stratum intermedium and papillary layer of the mouse enamel organ. J. Histochem. Cytochem., 45(11):148192, 1997.

Nakayama, Y.; Yang, L.; Mezawa, M.; Araki, S.; Li, Z.; Wang, Z.; Sasaki, Y.; Takai, H.; Nakao, S.; Fukae, M. \& Ogata, Y. Effects of porcine 25 $\mathrm{kDa}$ amelogenin and its proteolytic derivatives on bone sialoprotein expression. J. Periodontal Res., 45(5):602-11, 2010.

Nandasena, T. L.; Jayawardena, C. K.; Tilakaratne, W. M. \& Nanayakkara, C. D. Distribution pattern of cholinesterase enzymes in human tooth germs. Arch. Oral Biol., 55(8):561-9, 2010.

Ogata, Y.; Shimokawa, H. \& Sasaki, S. Purification, characterization, and biosynthesis of bovine enamelins. Calcif. Tissue Int., 43(6):389-99, 1988.

Oida, S.; Nagano, T.; Yamakoshi, Y.; Ando, H.; Yamada, M. \& Fukae, M. Amelogenin gene expression in porcine odontoblasts. J. Dent. Res., 81(2):103-8, 2002.

Paine, M. L. \& Snead, M. L. Tooth developmental biology: disruptions to enamel-matrix assembly and its impact on biomineralization. Orthod. Craniofac. Res., 8(4):239-51, 2005.

Papagerakis, P.; Lin, H. K.; Lee, K. Y.; Hu, Y.; Simmer, J. P.; Bartlett, J. D. \& Hu, J. C. C. Premature stop codon in MMP20 causing amelogenesis imperfecta. J. Dent. Res., 87(1):56-9, 2008

Ryu, O. H.; Hu, C. C. \& Simmer, J. P. Biochemical characterization of recombinant mouse amelogenins: protein quantitation, proton absorption, and relative affinity for enamel crystals. Connect. Tissue Res., 38(1-4):207-14, 1998.

Sasaki, S. \& Shimokawa, H. Enamel proteins: biosynthesis and chemistry. J. Dent. Res., 58(Spec. Issue B):765-72, 1979.

Simmer, J. P. \& Fincham, A. G. Molecular mechanisms of dental enamel formation. Crit. Rev. Oral Biol. Med., 6(2):84-108, 1995.

Simmer, J. P. \& Hu, J. C. Expression, structure, and function of enamel proteinases. Connect. Tissue Res., 43(2-3):441-9, 2002.

Simmer, J. P.; Lau, E. C.; Hu, C. C.; Aoba, T.; Lacey, M.; Nelson, D.; Zeichner-David, M.; Snead, M. L.; Slavkin, H. C. \& Fincham, A. G. Isolation and characterization of a mouse amelogenin expressed in Escherichia coli. Calcif. Tissue Int., 54(4):312-9, 1994.

Smith, C. E.; Pompura, J. R.; Borenstein, S.; Fazel, A. \& Nanci, A. Degradation and loss of matrix proteins from developing enamel. Anat. Rec., 224(2):292-316, 1989.

Smith, C. E. Cellular and chemical events during enamel maturation. Crit. Rev. Oral Biol. Med., 9(2):128-61, 1998.

Sumita, Y.; Honda, M. J.; Ueda, M.; Asahina, I. \& Kagami, H. Differential effects of growth differentiation factor- 5 on porcine dental papilla- and follicle-derived cells. Growth Factors, 28(1):56-65, 2010.
Sun, Z.; Fan, D.; Fan, Y.; Du, C. \& Moradian-Oldak, J. Enamel proteases reduce amelogenin-apatite binding. J. Dent. Res., 87(12):1133-7, 2008.

Tanimoto, K.; Le, T.; Zhu, L.; Chen, J.; Featherstone, J. D.; Li, W. \& DenBesten, P. Effects of fluoride on the interactions between amelogenin and apatite crystals. J. Dent. Res., 87(1):39-44, 2008a.

Tanimoto, K.; Le, T.; Zhu, L.; Witkowska, H. E.; Robinson, S.; Hall, S.; Hwang, P.; Denbesten, P. \& Li, W. Reduced amelogenin-MMP20 interactions in amelogenesis imperfecta. J. Dent. Res., 87(5):451-5, 2008b.

Termine, J. D.; Belcourt, A. B.; Christner, P. J.; Conn, K. M. \& Nylen, M. U. Properties of dissociatively extracted fetal tooth matrix proteins. I. Principal molecular species in developing bovine enamel. J. Biol. Chem., 255(20):9760-8, 1980.

Torres-Quintana, M. A.; Gaete, M.; Hernandez, M.; Farías, M. \& Lobos, N. Ameloblastin and amelogenin expression in posnatal developing mouse molars. J. Oral Sci., 47(1):27-34, 2005.

Varun, B. R.; Bindu, J. N.; Sivakumar, T. T. \& Joseph, A. P. Matrix metalloproteinases and their role in oral diseases: A review. Oral Maxillofac. Pathol. J., 3(1):186-91, 2012.

Veis, A.; Tompkins, K.; Alvares, K.; Wei, K.; Wang, L.; Wang, X. S.; Brownell, A. G.; Jengh, S. M. \& Healy, K. E. Specific amelogenin gene splice products have signaling effects on cells in culture and in implants in vivo. J. Biol. Chem., 275(52):41263-72, 2000.

Zhang, Y.; Yan, Q.; Li, W. \& DenBesten, P. K. Fluoride down-regulates the expression of matrix metalloproteinase-20 in human fetal tooth ameloblast-lineage cells in vitro. Eur. J. Oral Sci, 114 Suppl. 1:105-10, 2006.

\section{Corresponding author: \\ Jairo Mariel Cárdenas PhD \\ Department of Morphology \& Orthodontics \\ Faculty of Stomatology \\ San Luis Potosí University \\ Av. Manuel Nava 2 \\ San Luis Potosí \\ S.L.P. Postal Code: 78290 \\ MÉXICO}

Telephone: 00524448262357 ext. 5122

E-mail: Ilairo@yahoo.com.mx

Received: 13-04-2016

Accepted: 24-04-2016 